\title{
Low RIN Value for RNA-Seq Library Construction from Long-Term Stored Seeds: A Case Study of Barley Seeds
}

\author{
Marta Puchta ${ }^{\circledR}$, Maja Boczkowska *(D) and Jolanta Groszyk \\ National Centre for Plant Genetic Resources, Plant Breeding and Acclimatization National Research Institute, \\ Radzików, 05-870 Błonie, Poland; m.puchta@ihar.edu.pl (M.P.); j.groszyk@ihar.edu.pl (J.G.) \\ * Correspondence: m.boczkowska@ihar.edu.pl
}

Received: 20 August 2020; Accepted: 8 October 2020; Published: 13 October 2020

\begin{abstract}
Seed aging is a complex biological process and its fundamentals and mechanisms have not yet been fully recognized. This is a key issue faced by research teams involved in the collection and storage of plant genetic resources in gene banks every day. Transcriptomic changes associated with seed aging in the dry state have barely been studied. The aim of the study was to develop an efficient protocol for construction of RNA-Seq libraries from long-term stored seeds with very low viability and low RNA integrity number (RIN). Here, barley seeds that have almost completely lost their viability as a result of long-term storage were used. As a control, fully viable seeds obtained in the course of field regeneration were used. The effectiveness of protocols dedicated to RNA samples with high and low RIN values was compared. The experiment concluded that library construction from low viable or long-term stored seeds with degraded RNA $($ RIN $<3)$ should be carried out with extraordinary attention due to the possibility of uneven degradation of different RNA fractions.
\end{abstract}

Keywords: RNA-Seq; seed storage; RNA integrity number (RIN); Hordeum vulgare; degradation; mRNA stability; seed ageing

\section{Introduction}

Seed aging, seed deterioration or seed senescence has been defined as the loss of quality over time [1]. The most noticeable signs of seed aging at present are the increasing percentage of individuals in the seed lot that do not germinate (viability reduction) or germinate slowly (vigor reduction) over time. Seed aging is a complex biological feature in which several interrelated molecular, biochemical, physiological and metabolic processes are involved. All this makes the phenotype of seed longevity difficult to measure or predict, especially since it is also hard to assess, as the time before detectable changes occur is unknown. Walters et al. have shown that in a homogeneous seed lot there is usually a threshold at which individuals suddenly lose their viability [2]. In recent years, much effort has been put into research on seed aging processes, but the causes of seed senescence have still not been fully discovered. Furthermore, studies on the transcriptome in seeds that have been stored in a dry state and suffered loss of viability in the course of storage are very limited.

The transcriptome is a complete set of cell transcripts, characteristic for development or physiological state. Knowledge leading to understanding transcriptome activity is essential to interpret functional elements of the genome, reveal molecular components in cells and tissues and understand developmental processes [3].

The development of new high-throughput sequencing methods has provided an alternative method of mapping and quantification of transcripts [3]. RNA sequencing (RNA-Seq) uses the transcript profiling approach through deep sequencing and research and has changed the view on the 
complexity of transcripts. It provides a precise measurement of transcript expression level and their isoforms. The key aim of transcriptomic research is to catalogue different types of RNA molecules (mRNAs, sRNAs, non-coding RNAs) to determine the transcriptional structure of genes in relation to their starting point, splicing pattern and other posttranscriptional modifications to quantify changing expression levels of each transcript during development and under different environmental conditions. By contrast hybridisation, RNA-Seq is not limited to the detection of transcripts corresponding to a known genome sequence [3]. RNA-Seq has a very low, if any, existing background level compared to microarrays since DNA sequences can be unambiguously mapped to a unique genome region. RNA-Seq is an accurate method used to quantify the expression levels of transcripts as determined using RT-qPCR [4] and a spike-in RNA assay [5] with a known RNA concentration. It has high resolution and sensitivity, revealing many new transcribed regions and splicing isoforms of known genes, and allows mapping of exon and gene boundaries [6]. It enables absolute determination of the number of molecules in a cell population and comparison of the results between experiments. RNA-Seq analysis allows one to capture the dynamics of expression in different tissues under uncommon conditions without advanced data set normalization techniques [3]. An input for the construction of RNA-Seq libraries is the total RNA or individual fractions of e.g., mRNA, which is initially reverse transcribed to cDNA and subsequently ligated specific adaptors at one or both ends. Prepared libraries are amplified and sequenced from one end (single-end) or both ends (pair-end). Unlike sRNAs, which can be directly ligated to the adaptor, long RNA sequences have to be fragmented into smaller fragments ranging from 200 to $500 \mathrm{nt}$, which are compatible with the high throughput, next generation sequencing technology used in the experiment. Commonly used RNA fragmentation methods include hydrolysis or nebulization of RNA, while cDNA fragmentation is obtained by DNase I treatment and sonification [5].

A key aspect of RNAseq is to reduce the representation of redundant ribosomal RNA (rRNA) during the construction of libraries. rRNA is the most numerous fraction of total RNA, representing the majority (>80\% to $90 \%$ ) of molecules [7]. So far, several different solutions for reducing rRNA have been developed. In the literature, the following are most common: mRNA enrichment, ribosomal depletion and 3'mRNA counting. Probably the most widespread method used is poly (A)+ enrichment using oligo-dT coated beads performed prior to cDNA synthesis. However, the disadvantage of this method is elimination of non-rRNA populations, e.g., parts of non-coding RNAs. It may also introduce bias when analyzing low quality or low quantity RNA samples. The 3'mRNA counting method is based on reverse transcription using an oligo-dT primer [8]. After that the RNA template is removed and the second strand is synthesized using random primers [9]. The advantage of this method is that the direct number of readings reflects the number of transcripts of a given gene. cDNAs are only transcribed from the end of 3'RNA, and for each transcription only one copy of cDNA is generated [9]. The 3' mRNA counting method requires well-annotated genomes and in addition it is not recommended for testing splicing sites $[9,10]$. It was observed that the RNA-Seq analysis identified 15\% of transcripts with alternative splicing, while 3' mRNA counting only identified 6\% [9]. Another approach used in RNA-Seq libraries construction is rRNA depletion. There are currently three strategies for removing rRNAs. In the first one, rRNA is captured by complementary oligonucleotides coupled to paramagnetic beads and removed from the reaction. In the second method, rRNA is hybridized with oligos DNA and then RNA-DNA hybrids are degraded using RNase $H$. The third method involves transcribing total RNA on cDNA and preparing libraries with ZapR enzyme that targets ribosomal RNA sequences after conversion to cDNA [11]. Moreover, the rRNA depletion protocol may detect immature RNA (pre-RNA) apart from mature mRNA, while mRNA-Seq provides the highest sensitivity for detecting differences in gene expression, probably due to the larger fraction of readings mapped to the exome [12]. Zhao et al. [13] during research on blood and colorectal material showed that $220 \%$ and $50 \%$ more readings had to be sequenced using the rRNA depletion method to achieve the same level of exome coverage. 
The most recent method is RNA capture that uses capture probes targeted at known exons for enriching coding RNA fractions. It allows sequencing transcripts by targeting them with an excess of probes at multiple positions, even if poly(A) tails were lost. Therefore, it is ideally suited for the analysis of degraded samples like those extracted from formalin-fixed, paraffin-embedded (FFPE) tissue samples [14]. However, this technique is used in human rather than plant samples. The rapid progress in the sequencing and annotation of plant genomes offers the prospect of extensive application of this technique for the analysis of plant samples, especially for major crops.

The aim of this study was to develop a methodological approach for the construction of RNA-Seq libraries from long-stored barley seeds with very low viability. Here, enrichment of the mRNA fraction using oligo-dT-coated beads was selected because a parallel analysis of the miRNA and degradome was conducted. Therefore, the results obtained from RNA-Seq and degradome-Seq will be compatible. The same method of reducing redundant rRNA will facilitate the interpretation of the results. To optimize the protocol of library construction from barley seeds with low viability, the SMARTer Stranded RNA-Seq Kit (Takara) was selected as it is dedicated to the analysis of non-mammalian samples. Moreover, it allows the use of both highly degraded and good quality RNA. This made it possible to compare the efficiency and correctness of the library construction protocol in an unbiased way.

The step of RNA-Seq library construction is crucial for further transcriptomic studies in seed aging and the results obtained here can be translated to other species.

\section{Materials and Methods}

\subsection{Plant Material}

Experiment was carried out using grains from barley (Hordeum vulgare L.) cv. 'Damazy' harvested in 1972 . The grains, which after harvest and drying showed above $95 \%$ viability and $2.96 \%$ moisture content, were placed in air-filled stocks, hermetically sealed and stored at room temperature. In 2015, the grain parameters were remeasured. The viability was $2 \%$, moisture content $12.5 \%$. Grains from the same initial lot with $99.3 \%$ viability (6.32\% moisture content in 2015), preserved under gene bank conditions over the same period, were reproduced in a field trial in 2017 and used as reference sample. The grains obtained from the reproduction were dried in accordance with gene banks standards. Both grain samples, i.e., low viable (Lv) and reference sample (Rc), were used for RNA-Seq library preparation (Figure 1).

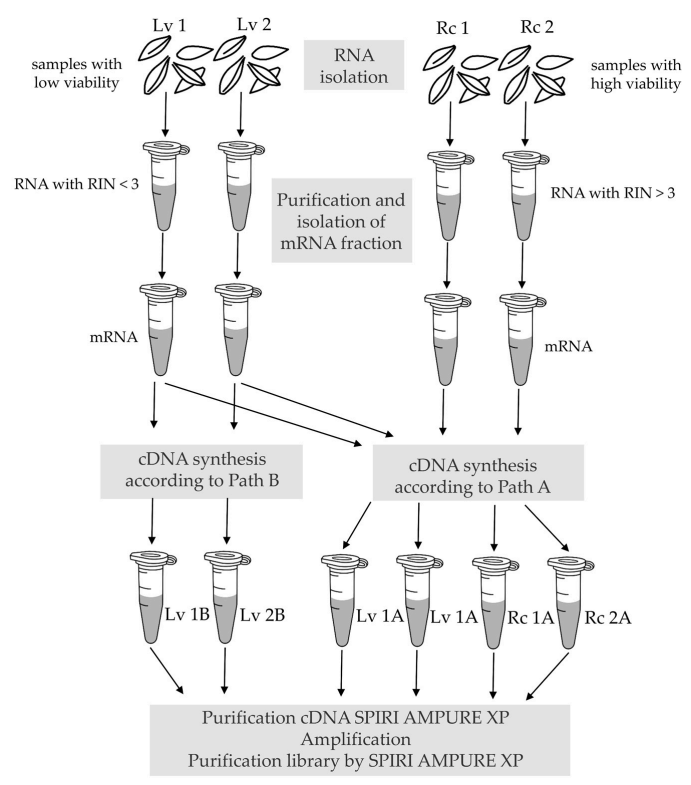

Figure 1. Diagram illustrating the experimental workflow (Rc-control samples with high viability, Lv-long-term stored samples with low viability; each sample represented by two biological replicates). 


\subsection{Total RNA Extraction}

Total RNA was extracted from 25 dry embryos from each sample ( $\mathrm{Lv}$ and Rc) in two biological replicates by crushing in liquid nitrogen and extracting using $1 \mathrm{~mL}$ of TRI Reagent (Sigma-Aldrich, Saint Louis, MO, USA) following the manufacturer's protocol in the presence of $0.1 \mathrm{~mL}$ 1-bromo-3-chloropropane (Sigma-Aldrich, Saint Louis, MO, USA). The analyses were performed in two repetitions due to the limited number of low viable seeds. RNA pellets were washed in $1 \mathrm{~mL}$ of $75 \%$ ethanol (POCH, Gliwice, Poland) and after drying were dissolved in $100 \mu \mathrm{L}$ of molecular grade water (A\&A Biotechnology, Gdynia, Poland). The RNA was completely dissolved after $90 \mathrm{~min}$ in $4{ }^{\circ} \mathrm{C}$, gently mixing every $30 \mathrm{~min}$. The quantity and purity were assessed by a NanoDrop 1000 spectrophotometer (NanoDrop Technologies, Willmington, DA, USA ). Absorbance at $260 \mathrm{~nm}$ and $280 \mathrm{~nm}$ was used to assess the purity of nucleic acid samples. The quality of isolated total RNA was evaluated using the Bioanalyzer 2100 (Agilent, Santa Clara, CA, USA) by Eukaryote Total RNA Nano set (Agilent, Santa Clara, CA, USA).

\subsection{Purification and Enrichment of the mRNA Fraction}

Batches containing $100 \mu \mathrm{g}$ of total RNA were purified from residual DNA using $10 \mu \mathrm{L}$ dsDNase (Thermo Fisher Scientific, Waltham, MA, USA), $10 \mu \mathrm{L} 10 \times$ dsDNase Buffer, and filled to the final $100 \mu \mathrm{L}$ volume with molecular grade water. The samples were mixed and centrifuged and then incubated for $2 \mathrm{~min}$ at $37^{\circ} \mathrm{C}$ in a preheated thermocycler (Applied Biosystem, Foster City, CA, USA). Total RNA after removing residual genomic DNA was used for mRNA enrichment using a Dynabeads Purification Kit for mRNA (Invitrogen, Carlsbad, CA, USA). For this purpose, $200 \mu \mathrm{L}$ of Dynabeads was added to the sterile tube and placed in a magnetic stand for $30 \mathrm{~s}$. In the next step, $80 \mu \mathrm{g}$ of total RNA suspended in the volume of $100 \mu \mathrm{L}$ was added to the beads (1:1 ratio) and mixed gradually for 5 min at room temperature. Beads with RNA attached to their surface were placed on a magnetic stand and $200 \mu \mathrm{L}$ washing buffer was added after the supernatant was removed. The washing step was repeated twice. Beads were air-dried and eluted in $20 \mu \mathrm{L}$ of sterile water. Beads were vortexed and then heated with mixing for $2 \mathrm{~min}$ at $65^{\circ} \mathrm{C}$ and $500 \mathrm{rpm}$ in a thermomixer (Biosan, Riga, Latvia). Afterwards, the tubes with beads were placed on a magnetic stand and $20 \mu \mathrm{L}$ of supernatant containing enriched mRNA fraction was transferred to the pre-cooled tube.

\section{4. cDNA Synthesis}

In the next stage of library construction, cDNA synthesis was performed using a SMARTer Stranded RNA-Seq Kit (Takara, Kusatsu, Japan). According to the manufacturer's recommendations, the cDNA synthesis protocol should depend on the quality of RNA measured by the RIN factor. For samples with RIN $>3$, path A should be followed, while for degraded samples with low RIN $<3$, path B is recommended. In pathway A, RNA is fragmented directly before cDNA synthesis by heat treatment in the presence of buffer. In pathway B, this step is omitted. Thus, samples with a low RIN value, i.e., originating from grains with low viability after long-term storage ( $\mathrm{Lv} 1 \mathrm{~B}$ and $\mathrm{Lv} 2 \mathrm{~B})$, were forwarded to pathway B. Analogously, samples with a high RIN value, i.e., isolated from non-stored seeds with a high viability (Rc $1 \mathrm{~A}$ and Rc $2 \mathrm{~A}$ ), were directed to path A. Furthermore, samples with a low RIN value were also redirected to path $\mathrm{A}$ ( $\mathrm{Lv} 1 \mathrm{~A}$ and Lv 2A) (Figure 1).

\subsubsection{Path A for Samples with RIN $>3$}

Initially, $8 \mu \mathrm{L}$ of mRNA ( $80 \mathrm{ng}), 1 \mu \mathrm{L}$ SMART Stranded N6 Primer $(12 \mu \mathrm{M})$, and $4 \mu \mathrm{L} 5 \times$ First Strand Buffer were used. Samples were incubated in a thermocycler for $5 \mathrm{~min}$ at $94{ }^{\circ} \mathrm{C}$ for RNA fragmentation and placed on ice for $2 \mathrm{~min}$. Immediately afterwards, the remaining components were added: $0.5 \mu \mathrm{L}$ DTT (100 mM), $0.5 \mu \mathrm{L}$ RNase Inhibitor (40 U/ $\mu \mathrm{L}), 2 \mu \mathrm{L}$ dNTP Mix (10 mM), $2 \mu \mathrm{L}$ SMARTer Stranded Oligo $(12 \mu \mathrm{M})$, and $2 \mu \mathrm{L}$ SMART Scribe RT $(100 \mathrm{U} / \mu \mathrm{L})$ in $20 \mu \mathrm{L}$ total volume. The reaction mix was 
incubated in a thermocycler (Applied Biosystem, Foster City, CA, USA ) for 90 min at $42{ }^{\circ} \mathrm{C}, 10 \mathrm{~min}$ at $70{ }^{\circ} \mathrm{C}$ and cooled at $4{ }^{\circ} \mathrm{C}$.

\subsubsection{Path B for Degraded Samples with RIN $<3$}

Initially, $8 \mu \mathrm{L}$ of mRNA (80 ng) sample and $1 \mu \mathrm{L}$ SMART Stranded N6 Primer $(12 \mu \mathrm{M})$ were used. Samples were incubated in a thermocycler for $3 \mathrm{~min}$ at $72{ }^{\circ} \mathrm{C}$ and placed on ice for $2 \mathrm{~min}$ and the other components were subsequently added: $4 \mu \mathrm{L} 5 \times$ First Strand Buffer, $0.5 \mu \mathrm{L}$ DTT (100 mM), $0.5 \mu \mathrm{L}$ RNase Inhibitor (40 U/ $\mu \mathrm{L}), 2 \mu \mathrm{L}$ dNTP Mix (10 mM), $2 \mu \mathrm{L}$ SMARTer Stranded Oligo $(12 \mu \mathrm{M})$, and $2 \mu \mathrm{L}$ SMART Scribe RT $(100 \mathrm{U} / \mu \mathrm{L})$ in total volume of $20 \mu \mathrm{L}$. The sample was then incubated for $90 \mathrm{~min}$ at $42{ }^{\circ} \mathrm{C}, 10 \mathrm{~min}$ at $70{ }^{\circ} \mathrm{C}$, and cooled at $4{ }^{\circ} \mathrm{C}$.

\subsection{Purification of $c D N A$ using SPIRI AMPURE XP}

All cDNA samples were purified using SPIRI AMPURE XP (Beckman Coulter, Brea, CA, USA) magnetic beads. After incubation, beads were vortexed for $30 \mathrm{~min}$ at room temperature and a volume of $20 \mu \mathrm{L}$ was added to each sample, pipetted 10 times and incubated for $8 \mathrm{~min}$ at room temperature. In the next stage, each sample was placed on a magnetic stand for $5 \mathrm{~min}$ in order to precipitate the magnetic beads. Then the supernatant was removed and $200 \mu \mathrm{L}$ of fresh $80 \%$ ethanol was added in order to wash the beads. After $30 \mathrm{~s}$, the supernatant was removed and magnetic beads were washed in ethanol again. Pellets were dissolved in $22 \mu \mathrm{L}$ of sterile water and used for amplification (cDNA solution contained SPIRI AMPURE XP beads).

\subsection{Amplification}

For amplification, $22 \mu \mathrm{L}$ of purified cDNA was used. For each mix, $25 \mu \mathrm{L} 2 \times$ SeqAmp PCR Buffer, $1 \mu \mathrm{L}$ Universal Forward PCR Primer $(12.5 \mu \mathrm{M}), 1 \mu \mathrm{L}$ Reverse PCR Primer $(12.5 \mu \mathrm{M})$ different for each sample, and $1 \mu \mathrm{L}$ SeqAmp DNA Polymerase were added. Samples were mixed and incubated in a thermocycler for $1 \mathrm{~min}$ at $94{ }^{\circ} \mathrm{C}$ followed by 10 cycles of: $15 \mathrm{~s}$ at $98^{\circ} \mathrm{C}, 15 \mathrm{~s}$ at $55^{\circ} \mathrm{C}, 30 \mathrm{~s}$ at $68^{\circ} \mathrm{C}$, and then cooled for $1 \mathrm{~min}$ at $4^{\circ} \mathrm{C}$.

\subsection{Purification of $c D N A$ Library by SPIRI AMPURE XP}

Purification of cDNA library was performed again after the amplification, this time adding $50 \mu \mathrm{L}$ of magnetic beads to each sample and the rest of the protocol as described above. The purified library was eluted in $20 \mu \mathrm{L}$ of sterile water. Samples were incubated at room temperature for 2 min and thereafter placed again on a magnetic stand for several minutes. The supernatant was transferred to a new tube.

Prepared libraries were evaluated qualitatively and quantitatively using the Qubit fluorimeter (Thermo Fisher Scientific, Waltham, MA, USA) by Qubit dsDNA HS Assay Kit (Thermo Fisher Scientific, Waltham, MA, USA) and automatic electrophoresis system Bioanalyzer 2100 using High Sensitivity DNA kit (Agilent, Santa Clara, CA, USA).

\subsection{NGS Sequencing}

After normalization, the libraries were sequenced on a HiSeq 4000 machine (Illumina, San Diego, CA, USA) in paired-end $2 \times 150 \mathrm{bp}$. The RNA-Seq data results have been qualitatively evaluated using the FastQC software [15]. RNA libraries were sequenced by Genomed S. A. (Warsaw, Poland).

\section{Results}

\subsection{RNA Quality}

Isolated total RNA was evaluated qualitatively and quantitatively, according to the recommendations of the RNA-Seq library manufacturers for Next Generation Sequencing, the RIN (RNA Integrity Number) was measured. The analyses were performed for long-term stored barley 
grains with low viability and fresh grains after field reproduction with high viability. Due to the limited number of low viability grains, the analyses were performed in two biological replicates. According to the results, samples from fresh grains (Rc 1 and Rc 2) had good quality RNA and the RIN of the samples was 7.8 and 7.9, respectively (Figure 2). For samples from long-term stored grains (Lv 1, Lv 2), RNA showed a high grade of degradation, as indicated by RIN 2.5 and 2.8 (Table 1). The electropherograms in Figure 2 show a high grade of degradation of $18 \mathrm{~S}$ and $28 \mathrm{~S}$ rRNA subunits.

(a)
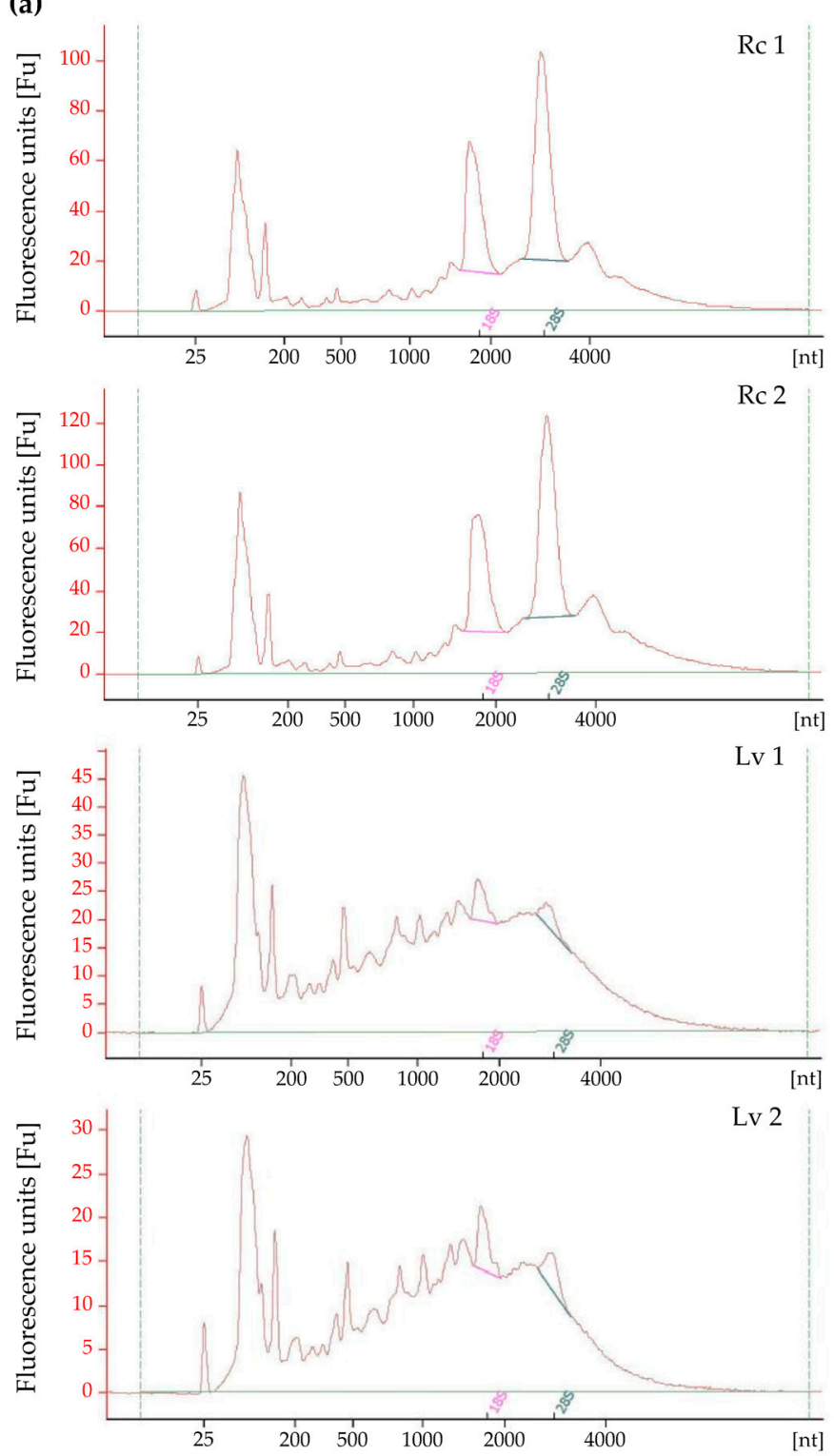

(b)

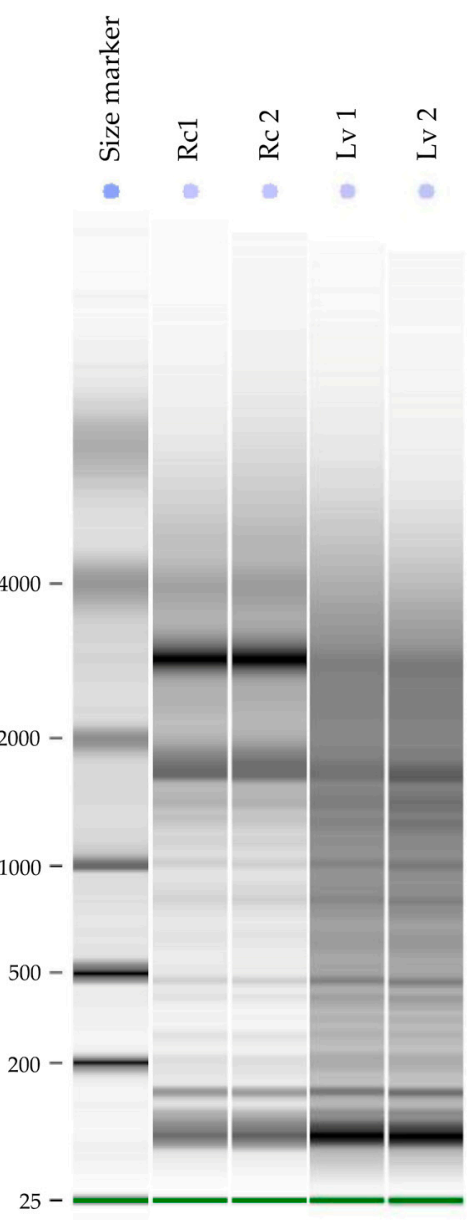

Figure 2. Results of total RNA extracted using the method described in this study. Extractions were made from four different samples (Rc—control samples with high viability, Lv-long-term stored samples with low viability; each sample represented by two biological replicates) and run on an Agilent 2100 Bioanalyzer using the Eukaryote Total RNA Nano kit (Agilent). (a) Agilent bioanalyzer chromatograms of total RNA; (b) Agilent bioanalyzer gel-like image of total RNA. 
Table 1. Sample parameters obtained by the automatic electrophoresis Bioanalyzer 2100 (Rc—control samples with high viability, Lv-long-term stored samples with low viability; each sample represented by two biological replicates).

\begin{tabular}{cccccc}
\hline & Samples & Rc 1 & Rc 2 & Lv 1 & Lv 2 \\
\hline \multirow{4}{*}{ RIN } & 7.9 & 7.8 & 2.5 & 2.8 \\
& RNA Area & 1437.8 & 1837.6 & 1253.1 & 820.5 \\
& RNA Concentration [ng/ $\mu \mathrm{L}]$ & 1127.0 & 1441.0 & 983.0 & 643.0 \\
& rRNA Ratio [28S/18S] & 1.4 & 1.4 & 0.6 & 0.7 \\
& Start size [nt] & 1609.0 & 1590.0 & 1644.0 & 1616.0 \\
& End size [nt] & 2193.0 & 2196.0 & 1973.0 & 1951.0 \\
& Area [\%] & 147.2 & 181.8 & 15.7 & 14.8 \\
& \% of total area & 10.2 & 9.9 & 1.3 & 1.8 \\
& Start size [nt] & 2615.0 & 2588.0 & 2748.0 & 2653.0 \\
& End size [nt] & 3555.0 & 3559.0 & 3432.0 & 3293.0 \\
& Area [\%] & 213.3 & 257.2 & 9.5 & 9.7 \\
& \% of total area & 14.8 & 14.0 & 0.8 & 1.2 \\
\hline
\end{tabular}

\section{2. $m R N A$ Enrichment}

In the next step, as foreseen by the protocol, a dsDNase enzyme was used to remove contaminating DNA in RNA preparations. After decontamination, the sample concentration was about $900 \mathrm{ng} / \mu \mathrm{L}$, which is about $45 \%$ of the initial samples for both low and high RNA, except for the Lv 2B sample, whose initial concentration was lower, and the recovery of the sample after dsDNase use was as high as $70 \%$.

To prepare the RNA-Seq libraries, the mRNA fraction was enriched by oligo(dT) magnetic beads. After the reaction, the mRNA fraction was about $140 \mathrm{ng} / \mu \mathrm{L}$ in Rc 1 and Rc 2 samples, which was $13 \%$, while for samples with low RIN, the concentration ranged from $62 \mathrm{ng} / \mu \mathrm{L}$ to $90 \mathrm{ng} / \mu \mathrm{L}$ (Table 1 ), which was up to $10 \%$ on average. The amounts of mRNA were consistent with the literature data [16].

\subsection{Library Construction}

The libraries were prepared according to the Takara protocol (SMARTer Stranded RNA-Seq) (Figure 3), which assumes two ways of preparing libraries depending on the RIN. For Rc 1 and Rc 2 samples with high RIN, cDNA synthesis was performed according to path A (Figure 1). The final library concentration prepared according to path A was $14.07 \mathrm{ng} / \mu \mathrm{L}$ (Rc 1 ) and $13.82 \mathrm{ng} / \mu \mathrm{L}$ (Rc 2), respectively (Table 2). Length distribution of fragments in prepared libraries was evaluated electrophoretically. The highest concentration was observed in the range from 250 to $600 \mathrm{bp}$. The highest distribution of Rc 1A fragments was observed for $259 \mathrm{bp}$ and was $2038.59 \mathrm{ng} / \mu \mathrm{L}$, while for Rc $2 \mathrm{~A}$ it was $1906.00 \mathrm{ng} / \mu \mathrm{L}$ (Table S1). 


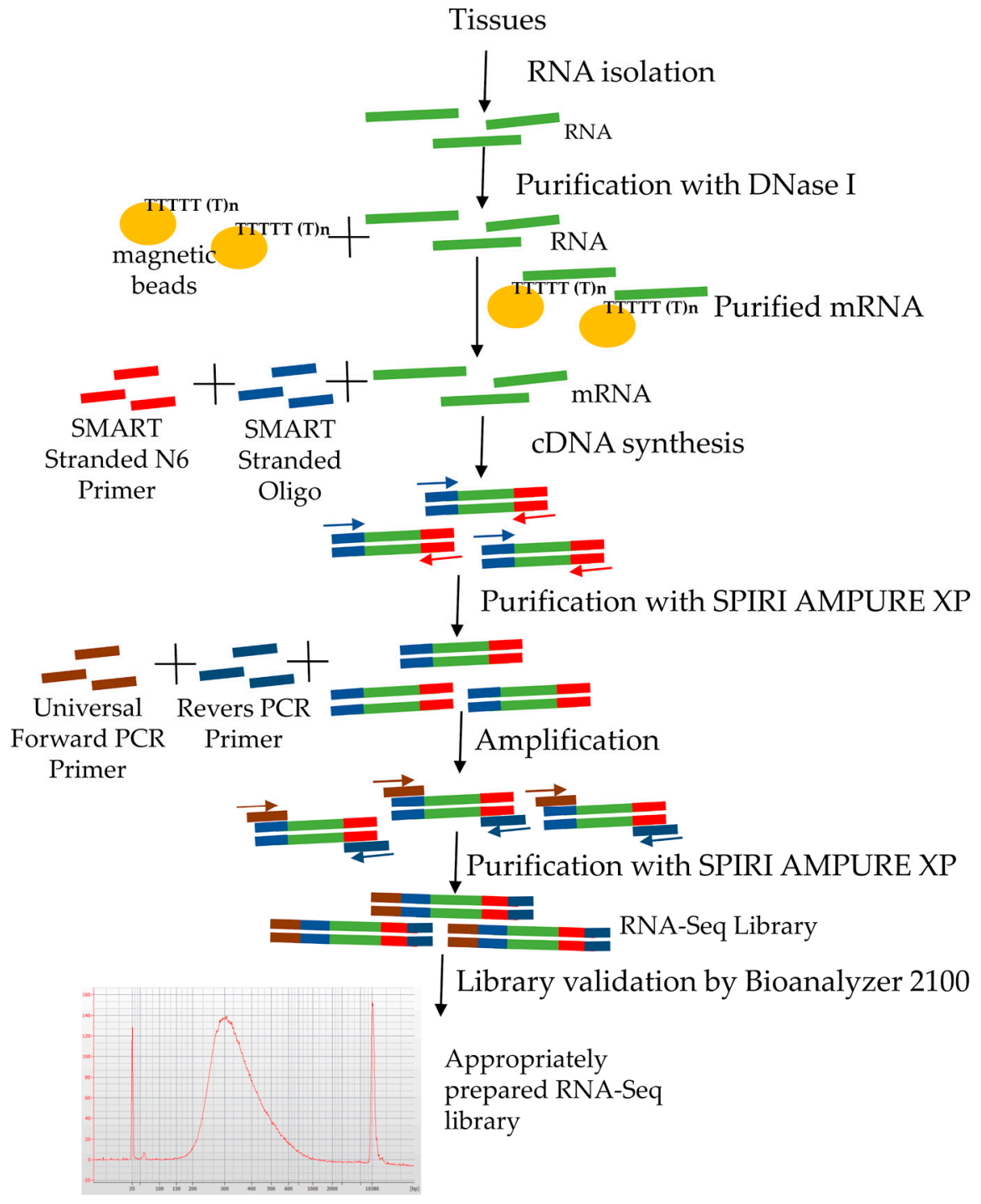

Figure 3. Stages of RNA-Seq library preparation.

Table 2. RNA, mRNA and library concentration (Rc - control samples with high viability, Lv-long-term stored samples with low viability; each sample represented by two biological replicates, A —CDNA synthesis path for samples with RIN > 3, B-cDNA synthesis path for samples with low $\operatorname{RIN}<3$ ).

\begin{tabular}{ccccccc}
\hline Sample ID & Rc 1A & Rc 2A & Lv 1B & Lv 2B & Lv 1A & Lv 2A \\
\hline RNA concentration after isolation $[\mathrm{ng} / \mu \mathrm{LL}]^{*}$ & 2103.51 & 2148.00 & 1932.05 & 1256.31 & 1932.05 & 1256.31 \\
RNA concentration after DNA & 900.40 & 901.56 & 906.50 & 904.28 & 906.50 & 904.28 \\
$\quad$ removal $[\mathrm{ng} / \mu \mathrm{L}]^{*}$ & 126.72 & 124.56 & 90.61 & 62.88 & 90.61 & 62.88 \\
mRNA fraction concentration $[\mathrm{ng} / \mu \mathrm{L}]^{*}$ & 11.1 & 11.31 & 0.76 & 0.82 & 5.38 & 5.4 \\
\hline library concentration $[\mathrm{ng} / \mu \mathrm{L}]^{* *}$ &
\end{tabular}

${ }^{*}$ measured by NanoDrop 1000, ** measured by Qubit.

For the Lv samples with low RIN, a cDNA synthesis was performed in accordance with path A ( $\mathrm{Lv} 1 \mathrm{~A}$ and Lv 2A) and path B (Lv 1B and Lv 2B). During electrophoretic analysis, the library was prepared according to path $B$, which is preferred for degraded total RNA, and the highest distribution of fragments was observed above $450 \mathrm{bp}$. The highest concentration for samples Lv 1B was observed for $880 \mathrm{bp}$ fragments (concentration $115.08 \mathrm{ng} / \mu \mathrm{L}$ ) and for Lv 2B $887 \mathrm{bp}$ (concentration $130.23 \mathrm{ng} / \mu \mathrm{L}$ ) (Figure 2). The final concentration of libraries constructed according to path $B$ was $0.76 \mathrm{ng} / \mu \mathrm{L}$ and $0.82 \mathrm{ng} / \mu \mathrm{L}$ for $\mathrm{Lv} 1 \mathrm{~B}$ and $\mathrm{Lv} 2 \mathrm{~B}$, respectively. The results indicate abnormal libraries, which is indicated 
by a high proportion of long DNA fragments and low final library concentrations. This indicates that mRNA integrity was not substantially decreased. However, for the construction of libraries for Lv samples according to path A for undegraded samples (omitting the low RIN value), the correct length distribution of DNA fragments in the libraries was observed. These results indicate that regardless of the low RIN, the appropriate electrophoretic RNA pattern was maintained and the mRNA is of good quality.

The libraries had the highest concentration of fragments of 280 to $500 \mathrm{bp}$ in length. The highest concentration in sample Lv 1A was observed for fragments of $288 \mathrm{bp}$ length, which was $2138.73 \mathrm{ng} / \mu \mathrm{L}$, and for samples Lv 2A of $286 \mathrm{bp}$, where the concentration was $1436.54 \mathrm{ng} / \mu \mathrm{L}$. The constructed libraries had the final concentration in $\mathrm{Lv}-1 \mathrm{~A} 5.38 \mathrm{ng} / \mu \mathrm{L}$ and in $\mathrm{Lv} 2 \mathrm{~A} 5.4 \mathrm{ng} / \mu \mathrm{L}$ (Figure 4).
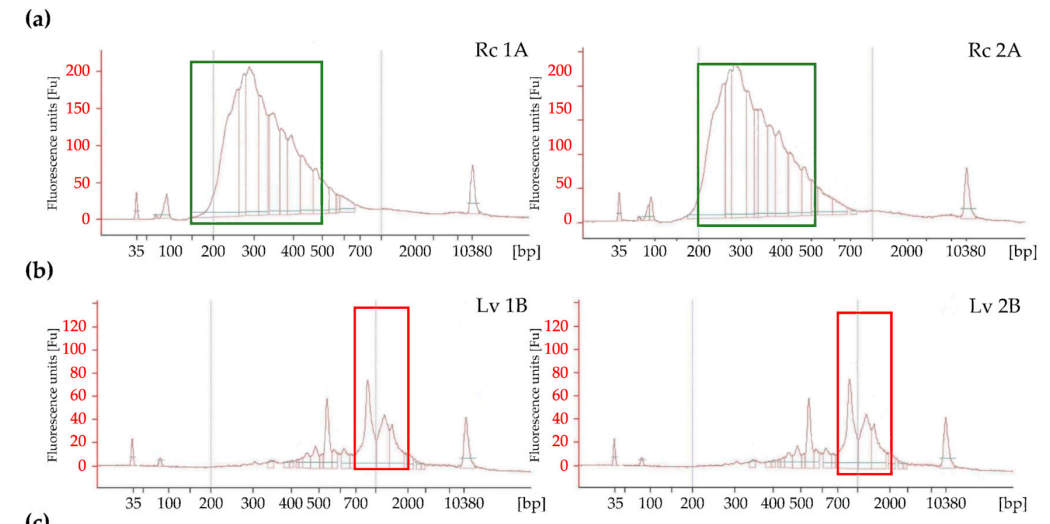

(c)
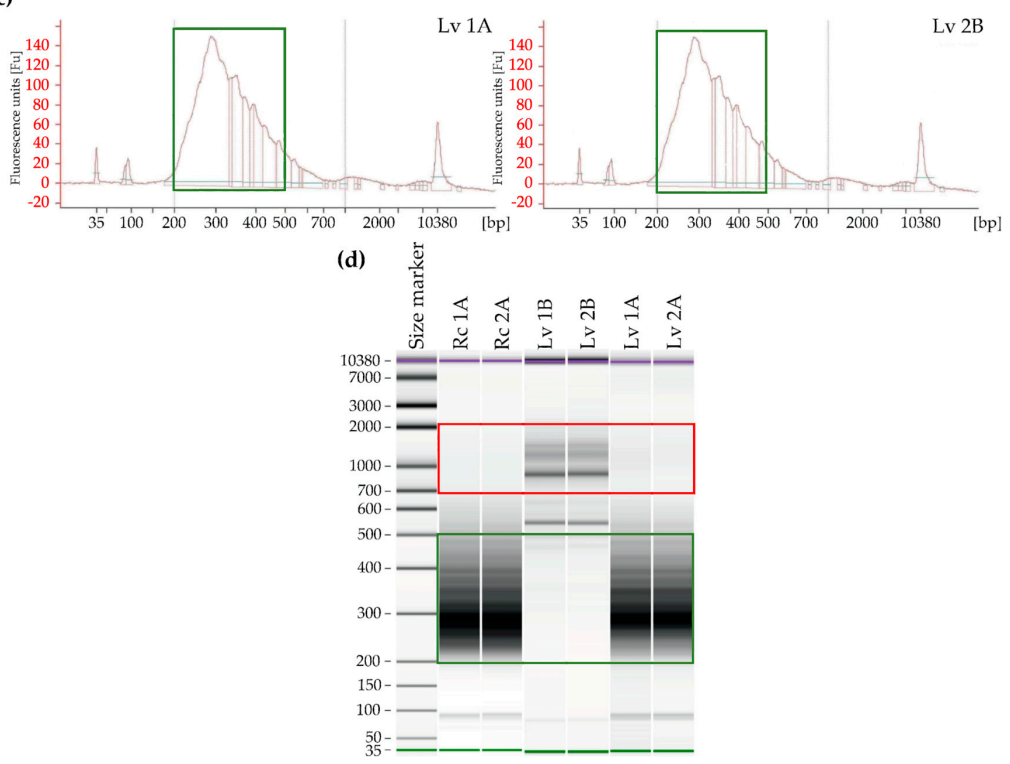

Figure 4. Densitometry validation and quantification of final RNA-Seq cDNA libraries prior to Illumina sequencing, using an Agilent 2100 Bioanalyzer and the High Sensitivity DNA kit (Beckman Coulter, Brea, CA, USA). The outermost peaks represent a size marker. RNA-Seq cDNA libraries were prepared from two replicates of RNA extracted from barley grains: (a) control samples with high viability according to the path $\mathrm{A}$; (b) long-term stored samples with low viability according to the path B; (c) long-term stored samples with low viability according to the path $\mathrm{A}$; (d) electrophoresis run of the cDNA libraries by the Bioanalyzer. The green and red frames indicate correct and incorrect fragment size range in the libraries, respectively.

\subsection{NGS Sequencing}

As a result of Rc 1A, Rc 2A, Lv 1A and Lv 2A libraries sequencing, 28 to 39 million raw reads were obtained for each of them (Table 3). Due to an incorrect length range, the Lv 1B and Lv 2B libraries were 
not directed to sequencing. For each library, the per base sequence quality (Phred score) was nearly 40. The average percentage of GC content in each library was 55\%. The sequenced fragments were in the range of 15-150 bp. Detailed information can be found in the supplementary files (Figures S1-S6).

Table 3. Qualitative report of RNA-Seq results from QC report analysis.

\begin{tabular}{ccccc}
\hline Samples & Rc 1A & Rc 2A & Lv 1A & Lv 2A \\
\hline \multicolumn{5}{c}{ Forward } \\
\hline Number of reads & $37,648,549$ & $38,165,239$ & $28,512,788$ & $36,711,845$ \\
Number of bases & $5,061,029,534$ & $4,977,869,871$ & $3,498,639,578$ & $5,067,910,888$ \\
Read length & $15-150$ & $15-150$ & $15-150$ & $15-150$ \\
\%GC & 55 & 55 & 55 & 55 \\
\hline \multicolumn{5}{c}{ Reverse } \\
Number of reads & $37,648,549$ & $38,165,239$ & $28,512,788$ & $36,711,845$ \\
Number of bases & $5,012,350,442$ & $4,932,157,953$ & $3,466,518,530$ & $5,013,123,377$ \\
Read length & $15-150$ & $15-150$ & $15-150$ & $15-150$ \\
\%GC & 54 & 54 & 54 & 54 \\
\hline
\end{tabular}

\section{Discussion}

Overall, RNA integrity is the major factor affecting the quality of sequencing data [17]. Therefore, the protocols of RNA-Seq libraries require samples with high-quality RNA. Prior to the construction of the libraries, it is necessary to assess RNA integrity number (RIN), which has become a widely accepted standard for quality measurement and has proven to be more accurate than UV spectrophotometric measurements and pure ribosomal RNA ratios [18]. Electrophoretic techniques have been widely used to evaluate RNA degradation to separate molecules by size in the sample. Historically, integrity evaluation was performed using electrophoresis in an agarose gel stained with ethidium bromide, and usually, the gel showed two bands; $28 \mathrm{~S}$ and $18 \mathrm{~S}$ rRNA. In 1999, the Bioanalyzer Agilent 2100 was introduced to separate DNA, RNA, and protein samples [18]. This was an automated system, using micro-fluid technology that provides electrophoretic separation of samples in an automated and reproducible manner [19]. Small amounts of samples are separated in the micro-fabricated chip channels according to their molecular weight and then detected by laser detection. The result is an electropherogram in which the amount of changed fluorescence correlates with the amount of RNA of a given size. The software calculates the ratio of two ribosomal bands. The RIN measurement is based on a machine learning algorithm that uses a capillary electrophoresis pathway and not just on the ratio of ribosomal subunits, although it is highly dependent on it. It provides a numerical score (range 1-10) for RNA quality. A higher RIN value indicates a higher degree of RNA integrity [20]. It is generally accepted that for samples with high inter granularity, the RIN level should be about 7-8. Most commercially available RNA-Seq library preparation kits require a high RIN value of the input RNA for proper library construction. However, the measurement of RIN has several weaknesses, which include the RIN dependence on $18 \mathrm{~S}$ and $28 \mathrm{~S}$ ribosomal RNA, because ribosomal indicators have usually shown low correlation with RNA integrity [21]. Another disadvantage of the RIN technique is that it maps RNA integrity, but it does not directly measure mRNA integrity, which is the main genetic material used in the construction of the libraries [22]. On the other hand, the complexity of RNA analysis results in a large impact of the integrity and abundance of the input RNA on the quantification of transcripts, regardless of whether it is performed by qPCR, microarray or RNA-Seq $[17,23,24]$. Degraded samples during sequencing show an insufficient representation of long transcripts and overexpression of short transcripts [17].

RNA degradation is an integral part of cellular metabolism and regulation of gene expression [25,26]. mRNA molecules are mostly short-lived, their persistence varies from several hours to several days and usually results from posttranscriptional regulation of mRNA and targeted decomposition of damaged RNA $[27,28]$. It has been estimated that the half-life of typical mRNAs ranges from 1 to 
$30 \mathrm{~h}$ and that cell degradation progresses also after death [29]. However, transcripts in dead cells as well as degradation of an isolated RNA are not subjected to physiological processes occurring in a normally functioning cell. It is not clear whether the RNA degradation occurs randomly or is related to the specific properties of the transcript [30]. It was found that in most cases, given the results of RNA-Seq analyses, the most efficient approach includes all samples regardless of their quality [30]. Using RIN as the only quality assessment was questionable because RIN with a value of 2.5 and 2.8 for long-term stored barley seeds as well as 7.9 and 7.8 for reference samples was derived from ribosomal integrity and the process of degradation of mRNA transcripts may be species-specific, which is not necessarily reflected in RIN [31]. The expression of mRNAs was strictly regulated and transcripts were degraded at different rates by different mechanisms, partly in relation to their biological function [32]. According to Romero et al. [30], three approaches can be adopted to deal with reduced quality samples. First, samples with high RNA degradation could be rejected, but this could cause decrease the chance of obtaining unique results. Second, assuming that all types of transcripts disintegrate at a similar rate in respect to gene expression, RNA integrity can be estimated by using a standardization procedure. Third, the RIN value can also be assumed, if different transcripts decay at different rates, and these rates are consistent for a given level of RNA degradation [30]. The size distribution of undamaged RNA molecules is more diverse than DNA, therefore distinguishing large fragmented mRNA molecules from undamaged, smaller mRNA molecules is very difficult [33].

An interesting case is RNA in dry seeds, where transcripts persist even for decades until germination begins [34]. To survive, metabolic activity is switched off and the cytoplasm transforms into a glassy state in cells of the dry seed [35]. Proteins required for germination can be translated from stored mRNA or long-lived mRNA templates in the mature dry seeds [36,37]. Over 10,000 mRNA species were detected in mature dry seed of Arabidopsis [38]. It has been postulated that rapid restoration of seed metabolism during imbibition resulted from the early translation of stored mRNAs [39]. The integrity of RNA, as well as DNA, impacts on seed longevity. Germability decrease is accompanied by a reduction in total RNA content and RNA integrity [33,40,41]. Fleming et al. [42] demonstrated in soybean that longer transcripts were more likely to be damaged and postulated that this was due to the impact of reactive oxygen species. It has been proven that, during germination, the seeds translate stored mRNAs using stored ribosomes [43,44]. However, whether stored mRNAs are sufficient to allow the completion of germination may be species-specific, i.e., appearance of the radicle $[36,37,45]$.

The results obtained in the study confirm RNA integrity loss expressed by lowering the RIN value resulting from the loss of the viability of barley grains due to ageing. However, due to the enrichment of samples with mRNA after isolation, the use of RIN appears to be inappropriate. Most RNA-Seq library construction kits are based on the enrichment of the mRNA fraction from the total RNA. This process is most often performed by using oligo(dT)-coated magnetic beads to capture the poly-adenylated end of mRNA and thereby discarding the problem of the highly abundant rRNA [46]. For seeds that have aged in a dry state, the degradation of different RNA fractions seems to occur at different rates. Major differences in RIN levels between samples with low germination capacity and fully viable samples were noted. However, as in Fleming et al. studies [33], they were not reflected by a substantial decrease in mRNA integrity. Using RIN values as an indicator of the degree of RNA degradation in such cases may lead to a library construction with inappropriate parameters, i.e., with an inaccurate distribution of fragment length. Treating samples with low RIN as highly degraded resulted in omitting the RNA fragmentation step during the construction of libraries, which resulted in a high concentration of overly long fragments inappropriate for correctly constructed libraries. According to the manufacturer's recommendations, degraded samples should be treated according to path B, which skips the RNA fragmentation in the first stage. In the case of long-term stored barley grains, this is an incorrect approach because the libraries prepared in this way had the wrong length distribution of library fragments. However, it should be kept in mind that the majority of RNA-Seq library kits were designed to analyze human or mammalian samples. So the starting materials are often formalin-fixed or paraffin-embedded, which causes RNA degradation to a small average size [47]. According to 
the manufacturer, path A is intended only for samples with $\mathrm{RIN}<3$, but as we have shown in our research, it is wrong. Samples with low RIN with a proper RNA pattern should be cut in the first stage of the libraries construction. Using the protocol for high quality samples with RIN $>3$, which includes the fragmentation step both for RNA samples obtained from low- and highly viable barley grains, allows one to get the correct concentration of fragments in the range of 250-600 bp. Although the protocol described above is based only on barley grains, we believe that it can also be successfully applied to seeds of other species stored in a dry state. A high grade of degradation of $18 \mathrm{~S}$ and $28 \mathrm{~S}$ rRNA subunits was also observed in RNA samples isolated from oat and rye grains, which substantially lost their viability due to long-term storage in a dry state [48]. Since rRNA depletion protocols were developed to overcome the problem of RNA degradation, libraries for RNA-Seq prepared in this way should also be treated as undegraded regardless of the RIN value for long-term stored seeds.

Many aspects like seed development, germination, viability, vigor or longevity have been investigated. Based on those results, our knowledge and understanding of aging processes and viability has progressed considerably [49-52]. Despite identifying so many mechanisms of seed aging, the genetic mechanisms underlying seed aging still remain to be discovered.

So far, the analyses of the transcriptome in stored seeds have been limited mainly to the termination of dormancy or accelerated artificial ageing of seeds due to short-term exposure to warm and humid conditions [41,53-57]. To the best of our knowledge, research on transcriptome changes related to ageing of dry stored seeds has been conducted only for soybean [33]. The analysis of transcriptome changes concerning the loss of viability during storage of seeds in a dry state is fundamental for gene banks where plant genetic resources are preserved for future.

\section{Conclusions}

Summarizing the results and the literature reports to date, the RIN value recommended by manufacturers of library construction kits does not indicate the level of degradation of the mRNA fraction in all cases. During the construction of transcriptome libraries from seeds with low viability after storage in a dry state and with low RIN, the assessment of the mRNA peak on the electropherography should be considered. The conducted tests indicate the presence of good quality mRNA in samples with low RIN. This indicates the need to apply the library design procedure for high RIN samples regardless of its value in order to obtain appropriate lengths and concentrations of cDNA fragments in the constructed libraries. The protocol and results presented here may provide an impulse to conduct transcriptomic research in samples with low RIN.

Supplementary Materials: The following are available online at http://www.mdpi.com/2073-4425/11/10/1190/s1, Figure S1: Mean sequencing quality across all bases; Figure S2: Mean quality score per read distribution; Figure S3: The content of each type of base; Figure S4: Combined content of G and C bases; Figure S5: Combined content of ambiguous bases; Figure S6: Sequence Length Distribution. Table S1: Concentration of fraction mRNA in library.

Author Contributions: Conceptualization, M.P. and J.G.; methodology, M.P. and J.G.; validation, J.G. and M.P.; formal analysis, J.G. and M.P.; investigation, M.P. and J.G.; resources, M.B.; writing-original draft preparation, M.P. M.B. and J.G.; writing-review and editing, M.P., J.G. and M.B.; visualization, M.P.; supervision, J.G. and M.B.; funding acquisition, M.B. All authors have read and agreed to the published version of the manuscript.

Funding: This research received no external funding.

Acknowledgments: The authors would like to express their greatest gratitude to Maciej Niedzielski for sharing the seeds for analysis, Monika Rakoczy-Trojanowska for her expert support at the research planning stage and Marek Koter for his constructive remarks.

Conflicts of Interest: The authors declare no conflict of interest.

\section{References}

1. Priestley, D.A. Seed Aging: Implications for Seed Storage and Persistence in the Soil; Comstock Associates: Ithaca, NY, USA, 1986; ISBN 978-0-8014-1865-5. 
2. Walters, C. Understanding the mechanisms and kinetics of seed aging. Seed Sci. Res. 1998, 8, $223-244$. [CrossRef]

3. Wang, Z.; Gerstein, M.; Snyder, M. RNA-Seq: A revolutionary tool for transcriptomics. Nat. Rev. Genet. 2009, 10, 57-63. [CrossRef] [PubMed]

4. Nagalakshmi, U.; Wang, Z.; Waern, K.; Shou, C.; Raha, D.; Gerstein, M.; Snyder, M. The Transcriptional Landscape of the Yeast Genome Defined by RNA Sequencing. Science 2008, 320, 1344-1349. [CrossRef] [PubMed]

5. Mortazavi, A.; Williams, B.A.; McCue, K.; Schaeffer, L.; Wold, B. Mapping and quantifying mammalian transcriptomes by RNA-Seq. Nat. Methods 2008, 5, 621-628. [CrossRef] [PubMed]

6. Morin, R.D.; Bainbridge, M.; Fejes, A.; Hirst, M.; Krzywinski, M.; Pugh, T.J.; McDonald, H.; Varhol, R.; Jones, S.J.M.; Marra, M.A. Profiling the HeLa S3 transcriptome using randomly primed cDNA and massively parallel short-read sequencing. BioTechniques 2008, 45, 81-94. [CrossRef]

7. O'Neil, D.; Glowatz, H.; Schlumpberger, M. Ribosomal RNA Depletion for Efficient Use of RNA-Seq Capacity. In Current Protocols in Molecular Biology; Ausubel, F.M., Brent, R., Kingston, R.E., Moore, D.D., Seidman, J.G., Smith, J.A., Struhl, K., Eds.; John Wiley \& Sons, Inc.: Hoboken, NJ, USA, 2013; p. mb0419s103. ISBN 978-0-471-14272-0.

8. Corley, S.M.; Troy, N.M.; Bosco, A.; Wilkins, M.R. QuantSeq. 3' Sequencing combined with Salmon provides a fast, reliable approach for high throughput RNA expression analysis. Sci. Rep. 2019, 9, 18895. [CrossRef]

9. Ma, F.; Fuqua, B.K.; Hasin, Y.; Yukhtman, C.; Vulpe, C.D.; Lusis, A.J.; Pellegrini, M. A comparison between whole transcript and 3' RNA sequencing methods using Kapa and Lexogen library preparation methods. BMC Genom. 2019, 20, 9. [CrossRef]

10. Tandonnet, S.; Torres, T.T. Traditional versus 3' RNA-Seq in a non-model species. Genom. Data 2017, 11, 9-16. [CrossRef]

11. Herbert, Z.T.; Kershner, J.P.; Butty, V.L.; Thimmapuram, J.; Choudhari, S.; Alekseyev, Y.O.; Fan, J.; Podnar, J.W.; Wilcox, E.; Gipson, J.; et al. Cross-site comparison of ribosomal depletion kits for Illumina RNA-Seq library construction. BMC Genom. 2018, 19, 199. [CrossRef]

12. Zhao, W.; He, X.; Hoadley, K.A.; Parker, J.S.; Hayes, D.; Perou, C.M. Comparison of RNA-Seq by poly (A) capture, ribosomal RNA depletion, and DNA microarray for expression profiling. BMC Genom. 2014, 15, 419. [CrossRef]

13. Zhao, S.; Zhang, Y.; Gamini, R.; Zhang, B.; von Schack, D. Evaluation of two main RNA-Seq approaches for gene quantification in clinical RNA sequencing: PolyA+ selection versus rRNA depletion. Sci. Rep. 2018, 8, 4781. [CrossRef] [PubMed]

14. Cieslik, M.; Chugh, R.; Wu, Y.-M.; Wu, M.; Brennan, C.; Lonigro, R.; Su, F.; Wang, R.; Siddiqui, J.; Mehra, R.; et al. The use of exome capture RNA-Seq for highly degraded RNA with application to clinical cancer sequencing. Genome Res. 2015, 25, 1372-1381. [CrossRef] [PubMed]

15. Andrews, S. FastQC: A Quality Control Tool for High Throughput Sequence Data. 2010. Available online: http://www.bioinformatics.babraham.ac.uk/projects/fastqc (accessed on 1 August 2020).

16. Wu, J.; Xiao, J.; Zhang, Z.; Wang, X.; Hu, S.; Yu, J. Ribogenomics: The Science and Knowledge of RNA. Genom. Proteom. Bioinform. 2014, 12, 57-63. [CrossRef] [PubMed]

17. Sigurgeirsson, B.; Emanuelsson, O.; Lundeberg, J. Sequencing Degraded RNA Addressed by 3' Tag Counting. PLOS ONE 2014, 9, e91851. [CrossRef]

18. Schroeder, A.; Mueller, O.; Stocker, S.; Salowsky, R.; Leiber, M.; Gassmann, M.; Lightfoot, S.; Menzel, W.; Granzow, M.; Ragg, T. The RIN: An RNA integrity number for assigning integrity values to RNA measurements. BMC Mol. Biol. 2006, 7, 3. [CrossRef]

19. Mueller, O.; Hahnenberger, K.; Dittmann, M.; Yee, H.; Dubrow, R.; Nagle, R.; Ilsley, D. A microfluidic system for high-speed reproducible DNA sizing and quantitation. Electrophoresis 2000, 21, 128-134. [CrossRef]

20. Sheng, Q.; Vickers, K.; Zhao, S.; Wang, J.; Samuels, D.C.; Koues, O.; Shyr, Y.; Guo, Y. Multi-perspective quality control of Illumina RNA sequencing data analysis. Brief. Funct. Genom. 2016, 16, elw035. [CrossRef]

21. Imbeaud, S. Towards standardization of RNA quality assessment using user-independent classifiers of microcapillary electrophoresis traces. Nucleic Acids Res. 2005, 33, e56. [CrossRef]

22. Wang, L.; Nie, J.; Sicotte, H.; Li, Y.; Eckel-Passow, J.E.; Dasari, S.; Vedell, P.T.; Barman, P.; Wang, L.; Weinshiboum, R.; et al. Measure transcript integrity using RNA-Seq data. BMC Bioinform. 2016, 17, 58. [CrossRef] 
23. Auer, H.; Lyianarachchi, S.; Newsom, D.; Klisovic, M.I.; Kornacker, K. Chipping away at the chip bias: RNA degradation in microarray analysis. Nat. Genet. 2003, 35, 292-293. [CrossRef]

24. Vermeulen, J.; De Preter, K.; Lefever, S.; Nuytens, J.; De Vloed, F.; Derveaux, S.; Hellemans, J.; Speleman, F.; Vandesompele, J. Measurable impact of RNA quality on gene expression results from quantitative PCR. Nucleic Acids Res. 2011, 39, e63. [CrossRef] [PubMed]

25. Garneau, N.L.; Wilusz, J.; Wilusz, C.J. The highways and byways of mRNA decay. Nat. Rev. Mol. Cell Biol. 2007, 8, 113-126. [CrossRef] [PubMed]

26. Rabani, M.; Levin, J.Z.; Fan, L.; Adiconis, X.; Raychowdhury, R.; Garber, M.; Gnirke, A.; Nusbaum, C.; Hacohen, N.; Friedman, N.; et al. Metabolic labeling of RNA uncovers principles of RNA production and degradation dynamics in mammalian cells. Nat. Biotechnol. 2011, 29, 436-442. [CrossRef]

27. Shoemaker, C.J.; Green, R. Translation drives mRNA quality control. Nat. Struct. Mol. Biol. 2012, 19, 594-601. [CrossRef]

28. Zhang, X.; Guo, H. mRNA decay in plants: Both quantity and quality matter. Curr. Opin. Plant Biol. 2017, 35, 138-144. [CrossRef]

29. Reiman, M.; Laan, M.; Rull, K.; Sõber, S. Effects of RNA integrity on transcript quantification by total RNA sequencing of clinically collected human placental samples. FASEB J. 2017, 31, 3298-3308. [CrossRef]

30. Gallego Romero, I.; Pai, A.A.; Tung, J.; Gilad, Y. RNA-Seq: Impact of RNA degradation on transcript quantification. BMC Biol. 2014, 12, 42. [CrossRef]

31. Feng, H.; Zhang, X.; Zhang, C. mRIN for direct assessment of genome-wide and gene-specific mRNA integrity from large-scale RNA-sequencing data. Nat. Commun. 2015, 6, 7816. [CrossRef]

32. Yang, E.; van Nimwegen, E.; Zavolan, M.; Rajewsky, N.; Schroeder, M.; Magnasco, M.; Darnell, J.E. Decay rates of human mRNAs: Correlation with functional characteristics and sequence attributes. Genome Res. 2003, 13, 1863-1872. [CrossRef]

33. Fleming, M.B.; Richards, C.M.; Walters, C. Decline in RNA integrity of dry-stored soybean seeds correlates with loss of germination potential. J. Exp. Bot. 2017, 68, 2219-2230. [CrossRef]

34. Dure, L.; Waters, L. Long-Lived Messenger RNA: Evidence from Cotton Seed Germination. Science 1965, 147, 410-412. [CrossRef]

35. Walters, C.; Wheeler, L.M.; Grotenhuis, J.M. Longevity of seeds stored in a genebank: Species characteristics. Seed Sci. Res. 2005, 15, 1-20. [CrossRef]

36. Rajjou, L.; Gallardo, K.; Debeaujon, I.; Vandekerckhove, J.; Job, C.; Job, D. The Effect of $\alpha$-Amanitin on the Arabidopsis Seed Proteome Highlights the Distinct Roles of Stored and Neosynthesized mRNAs during Germination. Plant Physiol. 2004, 134, 1598-1613. [CrossRef] [PubMed]

37. Sano, N.; Permana, H.; Kumada, R.; Shinozaki, Y.; Tanabata, T.; Yamada, T.; Hirasawa, T.; Kanekatsu, M. Proteomic Analysis of Embryonic Proteins Synthesized from Long-Lived mRNAs During Germination of Rice Seeds. Plant Cell Physiol. 2012, 53, 687-698. [CrossRef] [PubMed]

38. Nakabayashi, K.; Okamoto, M.; Koshiba, T.; Kamiya, Y.; Nambara, E. Genome-wide profiling of stored mRNA in Arabidopsis thaliana seed germination: Epigenetic and genetic regulation of transcription in seed: Molecular profiling in Arabidopsis seed. Plant J. 2005, 41, 697-709. [CrossRef]

39. Sano, N.; Ono, H.; Murata, K.; Yamada, T.; Hirasawa, T.; Kanekatsu, M. Accumulation of long-lived mRNAs associated with germination in embryos during seed development of rice. J. Exp. Bot. 2015, 66, 4035-4046. [CrossRef]

40. Kranner, I.; Chen, H.; Pritchard, H.W.; Pearce, S.R.; Birtić, S. Inter-nucleosomal DNA fragmentation and loss of RNA integrity during seed ageing. Plant Growth Regul. 2011, 63, 63-72. [CrossRef]

41. Chen, H.; Osuna, D.; Colville, L.; Lorenzo, O.; Graeber, K.; Küster, H.; Leubner-Metzger, G.; Kranner, I. Transcriptome-Wide Mapping of Pea Seed Ageing Reveals a Pivotal Role for Genes Related to Oxidative Stress and Programmed Cell Death. PLoS ONE 2013, 8, e78471. [CrossRef]

42. Fleming, M.B.; Patterson, E.L.; Reeves, P.A.; Richards, C.M.; Gaines, T.A.; Walters, C. Exploring the fate of mRNA in aging seeds: Protection, destruction, or slow decay? J. Exp. Bot. 2018, 69, 4309-4321. [CrossRef]

43. Basbouss-Serhal, I.; Soubigou-Taconnat, L.; Bailly, C.; Leymarie, J. Germination Potential of Dormant and Nondormant Arabidopsis Seeds Is Driven by Distinct Recruitment of Messenger RNAs to Polysomes. Plant Physiol. 2015, 168, 1049-1065. [CrossRef] 
44. Bai, B.; Peviani, A.; van der Horst, S.; Gamm, M.; Snel, B.; Bentsink, L.; Hanson, J. Extensive translational regulation during seed germination revealed by polysomal profiling. New Phytol. 2017, 214, 233-244. [CrossRef] [PubMed]

45. Jendrisak, J. The use of alpha-amanitin to inhibit in vivo RNA synthesis and germination in wheat embryos. J. Biol. Chem. 1980, 255, 8529-8533. [PubMed]

46. Davila, J.I.; Fadra, N.M.; Wang, X.; McDonald, A.M.; Nair, A.A.; Crusan, B.R.; Wu, X.; Blommel, J.H.; Jen, J.; Rumilla, K.M.; et al. Impact of RNA degradation on fusion detection by RNA-Seq. BMC Genom. 2016, $17,814$. [CrossRef] [PubMed]

47. Mullins, M.; Perreard, L.; Quackenbush, J.F.; Gauthier, N.; Bayer, S.; Ellis, M.; Parker, J.; Perou, C.M.; Szabo, A.; Bernard, P.S. Agreement in Breast Cancer Classification between Microarray and Quantitative Reverse Transcription PCR from Fresh-Frozen and Formalin-Fixed, Paraffin-Embedded Tissues. Clin. Chem. 2007, 53, 1273-1279. [CrossRef] [PubMed]

48. Boczkowska, M.; National Centre for Plant Genetic Resources, Plant Breeding and Acclimatization National Research Institute, Radzików, Poland. Personal communication, 2020.

49. Nonogaki, H.; Bassel, G.W.; Bewley, J.D. Germination-Still a mystery. Plant Sci. 2010, 179, 574-581. [CrossRef]

50. Rajjou, L.; Debeaujon, I. Seed longevity: Survival and maintenance of high germination ability of dry seeds. C. R. Biol. 2008, 331, 796-805. [CrossRef]

51. Ventura, L.; Donà, M.; Macovei, A.; Carbonera, D.; Buttafava, A.; Mondoni, A.; Rossi, G.; Balestrazzi, A. Understanding the molecular pathways associated with seed vigor. Plant Physiol. Biochem. 2012, 60, 196-206. [CrossRef]

52. Sreenivasulu, N.; Wobus, U. Seed-Development Programs: A Systems Biology-Based Comparison Between Dicots and Monocots. Annu. Rev. Plant Biol. 2013, 64, 189-217. [CrossRef]

53. Johnson, R.R.; Dyer, W.E. Degradation of endosperm mRNAs during dry afterripening of cereal grains. Seed Sci. Res. 2000, 10, 233-241. [CrossRef]

54. Bazin, J.; Langlade, N.; Vincourt, P.; Arribat, S.; Balzergue, S.; El-Maarouf-Bouteau, H.; Bailly, C. Targeted mRNA Oxidation Regulates Sunflower Seed Dormancy Alleviation during Dry After-Ripening. Plant Cell 2011, 23, 2196-2208. [CrossRef]

55. Gao, F.; Rampitsch, C.; Chitnis, V.R.; Humphreys, G.D.; Jordan, M.C.; Ayele, B.T. Integrated analysis of seed proteome and mRNA oxidation reveals distinct post-transcriptional features regulating dormancy in wheat (Triticum aestivum L.). Plant Biotechnol. J. 2013, 11, 921-932. [CrossRef] [PubMed]

56. El-Maarouf-Bouteau, H.; Meimoun, P.; Job, C.; Job, D.; Bailly, C. Role of protein and mRNA oxidation in seed dormancy and germination. Front. Plant Sci. 2013, 4. [CrossRef] [PubMed]

57. Cao, D.; Xu, H.; Zhao, Y.; Deng, X.; Liu, Y.; Soppe, W.J.J.; Lin, J. Transcriptome and Degradome Sequencing Reveals Dormancy Mechanisms of Cunninghamia lanceolata Seeds. Plant Physiol. 2016, 172, 2347-2362. [CrossRef] [PubMed]

(C) 2020 by the authors. Licensee MDPI, Basel, Switzerland. This article is an open access article distributed under the terms and conditions of the Creative Commons Attribution (CC BY) license (http://creativecommons.org/licenses/by/4.0/). 